8. Sytnik C. V. Osobystisnyi potentsial yak umova profesiinoi vzaiemodii / S. V. Sytnyk // Visnyk ONU imeni I. I. Mechnykova. Psykholohiia. - 2012. T. 17, Vyp. 8(20). - C. 168-174.
9. Faizullaev A. A. Motyvatsyonnye kryzysy lychnosty / A. A. Faizullaev // Psykholohycheskyi zhurnal. - 1989. - № 3. - S. 23-31.

Надійшла до редколегії 13.05.19

Alla Moskalova, PhD, Assoc. Prof.

Olga Vasiliga, Trainee researcher

SHEI "University of Education Management" NAES of Ukraine, Kyiv, Ukraine

\title{
PERSONAL POTENTIAL AS A BASIS OF HEALTHCARE WORKERS' PROFESSIONAL ACTIVITY
}

The article provides a theoretical analysis of various approaches to studying the concept of "personal potential" of an individual as a psychological phenomenon. The paper analyzes the current state of research of different approaches to the study of the personal potential of the individual, in particular the psychological characteristics of medical professionals, and investigates the psychological features of the personal capacity of medical professionals and their impact on professional activity. The personal potential of the individual is analyzed through the prism of concepts of self-realization, integral system of individual psychological features, system of internal restorative resources and dynamic psychological system. An analysis of the work of Ukrainian psychologists on the problem of researching the personal potential of medical professionals is given. On the basis of theoretical analysis, the concept of personal potential of medical workers is operationalized through the notion of vital, personal meaning of professional activity. It clarifies the specificity of healthcare workers' professional activity in the context of healthcare reform and determines the importance of personal potential in it. The article also focuses on psychological characteristics of healthcare workers' personal potential and their impact on the professional activity. The article identifies the spheres of realization of medical workers in their professional activity through the purpose of activity, the pursuit of self-improvement, as well as through professional, psychological, unlocking their potential. The study determined the degree of motivational self-regulation, styles of self-regulation and self-esteem of mental states of health workers. The psychological peculiarities of the personality potential of the personality affecting the professional activity of medical workers are revealed. The main obstacles to the disclosure of the personal potential of health care workers have been identified. Based on the analysis, recommendations were made regarding the prospects of further research into the personal potential of healthcare professionals.

Keywords: personal potential, professional activity, healthcare worker, healthcare worker's personal potential.

Алла Москалева, канд. психол. наук, доц.;

Ольга Василига, стажер-исследователь

ГВУЗ "Университет менеджмента образования" НАПН Украины, Киев, Украина

\section{ЛИЧНОСТНЫЙ ПОТЕНЦИАЛ КАК ОСНОВА ПРОФЕССИОНАЛЬНОЙ ДЕЯТЕЛЬНОСТИ МЕДИЦИНСКИХ РАБОТНИКОВ}

В статье осуществлен теоретический анализ различных подходов к изучению понятия "личностный потенциал" личности как психологического феномена. Выяснена специфика профессиональной деятельности медицинских работников в условиях реформирования медицинской отрасли. Определена роль личностного потенциала в профессиональной деятельности медицинских работников. Выявлены психологические особенности личностного потенциала медицинских работников и их влияние на профессиональную деятельность.

Ключевые слова: личностный потенциал, профессиональная деятельность, медицинский работник, личностный потенциал медицинского работника.

Bulletin of Taras Shevchenko National University of Kyiv. Series "Psychology". № 1(10), pp. 75-78 (2019) УДК 159.99

DOI: https://doi.org/10.17721/BSP.2019.1(10).19
ISSN $1728-3817$

(C) Taras Shevchenko National University of Kyiv, Publishing Center "Kyiv University", 2019

Ірина Норкіна, студ.

Київський національний університет імені Тараса Шевченка, Київ, Україна

\section{КРИЗОВЕ ВТРУЧАННЯ У ВИПАДКУ ПСИХОТРАВМУЮЧОЇ СИТУАЦІЇ}

Розглядаються питання діяльності психолога щодо допомоги особистості в кризовій ситуації. Важливим чинником кризового втручання є розуміння психологом сутності кризової ситуації, ступеню тяжкості й механізми їі переживання. Важливе місце відведено врахуванню стадій реагування особистості, що визначає стратегію $і$ напрямки професійного втручання. Аналізуючи процес кризового втручання у діяльності психолога (психологічної служби) виявлено важливі завдання які мають бути реалізовані: 1) зняття симптомів; 2) відновлення до кризового рівня функціонування; 3) усвідомлення тих подій, які приводять до стану дисбалансу; 4) виявлення внутрішніх ресурсів клієнта та членів сім'ї в різних формах допомоги для подолання кризи.

Ключові слова: психотравмуюча ситуація, мікро- і макротравми, криза, кризове консультування.

Вступ. Теорія кризового втручання використовується при наданні допомоги клієнту, що перебуває у нестійкому емоційном стані. Кризове втручання консультанта розглядається як цілеспрямована дія, що перериває ланцюг подій в житті клієнта, що призводять до кризи порушуючи нормальне існування людини. Відтак, методи кризового втручання застосовуються у випадках, коли до консультанта звертається клієнт у стані глибокої психологічної кризи і ситуація вимагає оперативного втручання. Дане питання залишається актуальним, саме тому, що людина протягом свого життя переживає мікро- та макротравми, які істотно впливають на якість iї життя. Кожна травмуюча ситуація 3 якою не може впоратись клієнт, вимагає втручання спеціаліста. Кризове втручання з боку психолога має місце не тільки під час терористичних атак чи надзвичайних подій, але й також у ті моменти, коли людина перебуває у кризі. Криза - це те, з чим стикається кожна людина! Ми можемо дати визначення, що криза - несподівана зміна в житті людини або зміна ії статусу, ролі, під час якої звичні копінг-стратегії та техніки вирішення проблем більше не $є$ ефективними, і як результат - людина відчуває тривогу, депресію, зниження емоційного фрону. Саме тому, на нашу думку, важливим $€$ висвітлення даної проблематики так як з нею стикається кожен у своєму житті, а зі сторони фахівця важливо розуміти, яким саме чином надавати кваліфіковану допомогу, розвивати стратегії вирішення проблем разом 3 клієнтом, проводити сфокусовану терапію направлену на негайне вирішення проблем та емоційних конфліктів у вигляді телефонних дзвінків, зустрічей, сімейних сесій.

Метою статті $€$ аналіз процесу кризового втручання у діяльності психологічної служби (психолога), яка виконує заходи для вирішення психотравмуючої ситуації та зменшення ії впливу на життя людини.

Криза (давньогрец. - рішення) в сучасному розумінні розглядається як відсутність балансу. Це ситуація або подія, коли людина стикається з перешкодою на шляху здійснення важливих життєвих цілей, яку не можна подолати звичними для людини адаптивними механізмами [7].

\begin{tabular}{|l|l|}
\hline \multicolumn{2}{|c|}{ Види кризи } \\
\hline Короткотривала (людина & Тривала, постійна (адаптація до \\
виходить 3 даної ситуації & ситуації кризи - квазі-адаптація, \\
і далі живе своїм життям) & незадоволення потреб здається \\
& нормальним) \\
\hline
\end{tabular}

() Норкіна Ірина, 2019 
Норми вирішення кризової ситуації коливаються у межах 46 тижнів від психотравмуючої ситуації.

Кризове втручання характеризується:

1) розумінням клієнта як людини, котра через надзвичайну подію тимчасово нездатна до нормального функціонування в суспільстві, але завдяки допомозі може відновити потенціал;

2) директивною позицією працівника психологічної служби, який в екстремальній ситуації бере всю відповідальність на себе;

3) терміновістю допомоги, оперативністю та доступністю надання послуг;

4) орієнтацією на пом'якшення впливу стресової події на клієнта;

5) мобілізацією всіх зусиль і можливостей клієнта для переборювання кризи і подолання проблем [7].

Нині виділяють дві фрорми до втручання в кризовій ситуації: кризове консультування та інтенсивний догляд.

Кризове консультування спрямоване на полегшення афекту, або сильної негативної емоції, налагодження спілкування, досягнення розуміння клієнтом його проблем і відчуттів, самооцінки; демонстрацію турботи, підтримку поведінки, спрямованої на подолання проблем.

Інтенсивний догляд - це стратегія втручання, яка передбачає перенесення відповідальності на професіоналів, котрі здійснюють догляд, організацію вирішення завдань, зниження рівня збудження і стресу, встановлення відповідних стосунків, вияв емпатії, відродження надії [7].

Отже, важливим аспектом теорії кризового втручання $\epsilon$ врахування емоційних реакцій людини на кризу та довгострокові зміни в їх здібностях протистояти щоденним проблемам. Вирішальне значення в роботі 3 клієнтами надається психологічним умовам: чіткому визначенню життєвих і перспективних цілей, задач, часових меж реалізації завдань, демонстрації досвіду вирішення проблем.

Ефективне втручання допомагає запобіпи важкій емоційній дезорганізації. Негайне і цілеспрямоване втручання знижує ймовірність прогресування розладів, дає хороші шанси на повне відновлення до кризового рівня функціонування, при цьому потреба в подальшій психотерапії, консультуванні або госпіталізації помітно знижується. Час в даному випадку є вирішальним фактором.

Процедура кризового втручання являє собою оперативну реакцію на проблему, що вимагає негайного вирішення. Жертви кризи часто дезорганізовані, схильні до впадання "в ступор" або небезпечної поведінки, тому вкрай важливо, щоб вони якомога швидше потрапили в поле зору фрахівця здатного вчасно і кваліфіковано відреагувати на ситуацію. Завдання фрахівця - допомогти жертві використовувати особистісні та соціальні ресурси, а в перспективі повернутися до кризового рівня функціонування [2].

3 цією метою рекомендується стандартний набір процедур. Пропоновані інструкції не встановлюють жорстких правил і не применшують значущість особистого стилю роботи психолога, а навпаки, покликані сприяти максимальному розкриттю його творчого потенціалу. Досить проста фрорма проведення кризового втручання диктується великою різноманітністю можливої поведінки жертв і різними міркуваннями, що виникають у фрахівця при спілкуванні з ними. Зазвичай психолог на початку втручання в тій чи іншій мірі сам відчуває тривогу. Прості інструкції дозволяють зберігати впевненість у тому, що незалежно від власного емоційного стану всі необхідні аспекти роботи з жертвами будуть охоплені [1].

Невідкладність - дії психолога повинні бути спрямовані на зниження рівня кризи з перших хвилин зустрічі з потерпілим. 3 часом криза посилюється і буде потрібний більш тривалий термін, перш ніж стануть помітні результати втручання. Контроль - жертви кризи часто погано контролюють себе і ситуацію, в якій опинилися. Саме тому, а також в цілях безпеки, фахівець повинен взяти на себе контроль ситуації і поведінки жертви. Це слід робити швидко поки буде необхідність. Іноді це займає всього декілька хвилин, а інколи процес триватиме досить довго. У разі, якщо людині, що знаходиться в кризі не буде надана своєчасна підтримка, це може призвести до важких розладів. Способи оволодіння ситуацією і підтримки контролю залежать від конкретних обставин і творчого потенціалу фахівця. Оцінка чому жертва опинилася в критичній ситуації саме в цей час? Які обставини сприяли кризі? Які спроби робила жертва або ії̈ оточення для вирішення стресової ситуації? Фахівець з кризового втручання повинен швидко і точно оцінити ситуацію, враховуючи особистісні особливості потерпілих для того, щоб розробити ефективні заходи подолання кризи. Одержана інформація повинна бути максимально точною і мати практичну значимість. Слід концентруватися лише на недавній події [2].

План дій - дії спеціаліста можуть допомогти жертві, але можуть і завдати шкоди. Отже, план втручання повинен бути ретельно продуманий. Найбільш значних і стійких результатів можна досягти лише в тому випадку, коли спеціалісту вдається допомогти жертвам самим опрацювати свої проблеми. Завдання фахівця полягає тільки в тому, щоб допомогти жертві повернутися до кризового рівня функціонування. Головна відмінність кризового втручання від психотерапії полягає в тому, що кризове втручання покликане допомогти взяти проблему під контроль, а не вирішити ії. Ефективне кризове втручання значно підвищує ймовірність успішного вирішення проблем в майбутньому [4].

Надання довідкової інформації та направлення до фахівців $\epsilon$ вкрай важливим, при необхідності треба своєчасно направити жертву до відповідного фрахівця або в громадську організацію для отримання додаткової допомоги. Подальше спостереження забезпечується по-різному, зокрема числі шляхом диспансерного спостереження за колишньою жертвою.

Теорія кризового втручання найбільш ефективно застосовується для допомоги людям, що переживають (або пережили) нещастя, допомагаючи знову адаптуватися до життя, вдосконалювати попередні рівні функціонування, опановувати новими способами боротьби 3 труднощами. Зазвичай це, терористичній атаки, природні катаклізми, сексуальне насилля чи насилля у родині, сімейні кризи, прояви агресивної поведінки по відношенню до себе чи інших, суїцидальні нахили [3].

Визначення тероризму говорить, що тероризм передбачає серйозне насильство над людиною, приносить серйозні збитки для власності, загрожує життю людини, створює серйозний ризик для здоров'я або безпеки суспільства. Незважаючи на різні визначення та аспекти терору, психологічні наслідки терактів часто не відрізняються від симптомів, пов'язаних з іншими травматичними подіями. Симптомів може не бути взагалі, або вони можуть бути присутні та варіюватися від легкого до серйозного. Кризове втручання часто фокусується на традиційному лікуванні, пов'язаному з стресовими розладами, такими як гострий або посттравматичний стресовий розлад (ПТСР).

Як приклад, ми можемо навести терористичну атаку, що відбулась 19 грудня 2016 року, під час якої була викрадена вантажівка, на якій пізніше навмисно в'їхали на різдвяний ярмарок поруч з Меморіальною церквою Кайзера Вільгельма в Берліні. В ході цієї атаки померло 12 людей та 48 осіб було госпіталізовано 3 травмами. Нападником визнали Аніса Амрі, громадянина Тунісу, який був застрелений італійською поліцією 23 грудня у Мілані. Відповідальність за теракт взяло на себе ісламістське угрупування [8]

Перш за все, ця ситуація викликала негайну реакцію; навколо події була паніка, хаос, страх. Така подія 
має в собі не тільки політичний аспект, а ще несе в собі великий психологічний вплив - стрес, не тільки для людей, що пережили її, а й для тих, хто стали свідками. В даному випадку рівень стресу у людей $є$ більшим, саме тому, що Німеччина вважається однією з найбезпечніших країн світу, з мінімально низьким рівнем злочинності. Люди ніколи не переживали події подібного масштабу, саме тому вона мала на них такий великий вплив, і досі навколо різдвяних ярмарок німецька влада встановлює бетонні укріплення.

Отже, перше кризове втручання що було зроблене німецьким урядом містило в собі відкриття локальних центрів швидкої допомоги для постраждалих не тільки фрізично, а й психологічно. За даними служб, до них в ті дні звернулось більше 130 осіб. На самому місці події працювали 309 поліцейських та 154 пожежних, третина з них повідомила про психологічну травму. Сенат організував 3-денний семінар для поліцейських, пожежних та співробітників соціальних служб, що був присвячений ПТСР та як з ним працювати, які перші кроки повинні бути надані жертвам. Такого роду зустрічі мають великий вплив та ефективність, так як дають відчуття соціальної підтримки та зниження відчуття самотності, що $€$ безсумнівно важливим фактором переживання ПТСР та зменшення ризику повторного травмування людини. Безпосереднє перше кризове втручання було надано волонтерським підрозділом, що співпрацює зі службами швидкої допомоги та пожежними бригадами у випадках надзвичайних подій. Одним із завдань волонтерських бригад було "просто перебувати поруч" 3 жертвами, що перебували у шоковому стані, забезпечити їм почуття безпечності та спокою, організувати для них необхідний вид допомоги. Консультант повинен бути готовим до різних реакцій, частіше за все неадекватних та вміти скерувати дану реакцію в потрібне русло, заспокоїти та надати допомогу. Також була надана психологічна допомога родичам та сім'ям постраждалих в терористичній атаці. Разом з Берлінською службою кризи була проведена подальша терапевтична робота 3 жертвами та тими, хто звернувся по допомогу в зв'язку 3 психологічною травматизацією після події. Така терапевтична робота $є$ важливою тому, що під час ПТСР підвищується ймовірність суїцидальних нахилів, всіх людей цієї групи ризику було взято в терапевтичний процес. Родичі жертв отримали фрінансову допомогу відповідно до закону про компенсацію потерпілим.

Психологічна неврівноваженість може характеризуватися відчуттям тривоги, безпорадності, страху, неадекватності, плутанини та дезорганізації. На цьому етапі особа, що зазначала психологічного порушення, може бути найбільш піддатливою та готовою до зовнішньої допомоги, тим самим надаючи можливість для змін поведінки та поверненню до попереднього рівня функціонування. Підводячи підсумок, криза випливає із негативного сприйняття людини ситуації. Психологи, соціальні працівники, працівники психічного здоров'я та терапевти навчаються надавати послуги в кризових ситуаціях. Ці працівники можуть допомогти особі або групі в умовах кризи шляхом прямого втручання, шляхом визначення альтернативних навичок, навичок подолання стресу або шляхом консультацій 3 іншими. Головними цілями консультанта в кризовій ситуації $€$ визначення, оцінка та втручання; якнайшвидше повернути людину до свого попереднього рівня функціонування; і зменшити будь-який негативний вплив на психічне здоров'я. Іноді під час цього процесу навчається новим навичкам та механізмам подолання, що призводять до змін як в жертві так і в консультанті.

Першим етапом у кризовому втручанні $€$ проведення повної оцінки пацієнта та його ситуації. Наступний етап полягає у вирішенні дисфункціональних переконань паці- єнта, створення варіантів подальших дій шляхом кооперації та, нарешті, створення надії. Терапевт вивчивши сильні сторони пацієнта для подолання критичної ситуації допомагає клієнтові зрозуміти його позитивний потенціал для виходу з кризи. Роблячи це, терапевт зможе забезпечити відчуття безпеки і змусити пацієнта почати знову контролювати своє життя, здійснити зміни, необхідні для руху вперед. Протокол поділений на п'ять етапів: 1) розвиток терапевтичних відносин та встановлення взаємозв'язку; 2) початкова оцінка тяжкості ситуації; 3) підтримка пацієнта, щоб оцінити та активізувати свої сильні сторони та ресурси; 4) спільна робота між пацієнтом і терапевтом для розробки плану позитивних дій; 5) тестування та перевірка нової поведінки та думок [6].

Що стосується різних психотерапевтичних підходів до травм, то експозиційна терапія досягла позитивних результатів при лікуванні ПТСР та складається 3 виявлення у пацієнта його травматичних спогадів або ситуацій, у безпечному середовищі та контрольованому режимі. Метою цих підходів $є$ зменшення рівня тривожності та відновлення функціонування пацієнта. Зазвичай експозиційна терапія включає в себе чотири основні компоненти: психонавчання, тренування дихання, образи стресової ситуації, нові образи.

Отже, в кризовій ситуації люди можуть почувати себе розбитими, травмованими, емоційно вигорівшими, розгубленими. Якщо ми говоримо про найважливішу психологічну підтримку, яку психологічні служби можуть надати комусь після травмуючої події, то це бути поруч, створити безпечне середовище, така соціальна підтримка може надаватися не тільки психологічними службами, а й родиною, друзями, колегами. По суті, будьяка дбайлива людина може забезпечити базовий рівень емоційної підтримки. Одним із важливих видів підтримки, яким можна забезпечити жертву - звичайний людський контакт, просто слухайте їх. Цього може бути достатньо для когось, аби заспокоїтись.

Деякі люди в стресовій ситуації хочуть говорити про те, що з ними сталося. Інші можуть бути налякані, заплутані та дезорієнтовані, вони хочуть просто сидіти в тиші та уникати спілкування з будь-ким. Важливо пам'ятати, що кожна людина має власний тип реакції та копінг-стратегії.

Висновки. Отже, поняття "криза" в житті людини позначається одночасно як складна ситуація, так і потенційна можливість змінитися і піднятись на вищий рівень буття. Важливим аспектом теорії кризового втручання $€$ врахування емоційних реакцій людини на кризу та довгострокові зміни в їх здібностях протистояти щоденним проблемам. Вирішальне значення в роботі 3 клієнтами надається психологічним умовам: чіткому визначенню життєвих і перспективних цілей, задач, часових меж реалізації завдань, демонстрації досвіду вирішення проблем. Саме тому так важлива підтримка людини у ситуації кризи.

Список використаних джерел

1. Auerbach S \& Kilmann P (1977) Crisis Intervention: A Review of Outcome Research. Psychological Bulletin, 84(6),1189-1217.

2. Myer, R, Lewis, J. \& James, R. (2013). The Introduction of a Task Model for Crisis Intervention. Journal of Mental Health Counseling, 35(2), 95-107.

3. Forbes, D., Creamer, M. C. Phelps, A J., Couineau, A Cooper, J. A Bryant, R. A., \& Raphael, B. (2007). Treating adults with acute stress disorder and post-traumatic stress disorder in general practice: a clinical update. Medical Journal of Australia, 187(2), 120.

4. Fusco, G. M. (2005). Crisis intervention. In Encyclopedia of Cognitive Behavior Therapy (pp. 146-150). Springer, Boston, MA

5. Rauch, S., Foa, E. (2006). Emotional processing theory (EPT) and exposure therapy for PTSD. Journal of Contemporary Psychotherapy, 36(2), 61.

6. Smead, V.S. (1988). Best practices in crisis intervention. In A. Thomas \& J. Grimes (Eds.), Best practices in school psychology (pp. 401-414). Washington, D.C.: National Association of School Psychologists.

7. https://studopedia.su/13 127368 teoriya-krizovogo-vtruchannya.htm

8. https://novynarnia.com/2016/12/23/v-italiyi-likvidovaniy-terorist-yakiyvchiniv-terakt-iz-vantazhivkoyu-v-berlini

Надійшла до редколегії 29.05.19 
Iryna Norkina, student

Taras Shevchenko National University of Kyiv, Kyiv, Ukraine

\section{CRISIS INTERVENTION IN THE CASE OF PSYCHOTRAUMATIC SITUATION}

The article deals with the questions of the psychologist's activity regarding assistance to the person in crisis. The basics of the theory of crisis intervention are outlined, the concept of crisis is operationalized and criteria for distinguishing between the concepts of micro trauma and micro trauma are introduced. The conceptual apparatus of the approach is developed in detail and the necessity of its unified understanding by practical psychologists is substantiated. The purpose of the article is to analyze the process of crisis intervention in the activity of the psychological service (psychologist), which takes measures to resolve the traumatic situation and reduce its impact on human life. An important factor in crisis intervention is the psychologist's understanding of the nature of the crisis, the severity and mechanisms of its experience. An important place is given to the stages of personal response, which determines the strategy and directions of professional intervention. Analyzing the process of crisis intervention in the activities of a psychologist (psychological service) identified important tasks that should be implemented: 1) the removal of symptoms; 2) recovery to crisis level of functioning; 3) awareness of those events that lead to an imbalance; 4) identify the internal resources of the client and family in various forms of crisis management assistance. The theoretical and practical recommendations given are outlined by the use of the voyage method, based on the real case of a crisis situation, which led to psychological trauma in participants and witnesses. As the above case is related to a terrorist act, the article also provides theoretical and methodological information regarding the specificity of the work of a psychologist with the concept of terrorism and the peculiarities of its impact on participants and witnesses of such acts. Based on the results of the case study, the author formulated practical recommendations for practicing psychologists on what to consider when dealing with an injury, especially if it was caused by an act of terrorism. The article concludes with the need to take into account the emotional reactions of a person to a crisis and the long-term changes in their ability to withstand daily problems. Crucial in dealing with clients is given to the psychological conditions that are discussed in detail in the article.

Keywords: traumatic situation, micro and macro traumas, crisis, crisis counseling.

Ирина Норкина, студ

Киевский национальный университет имени Тараса Шевченко, Киев, Украина

\section{КРИЗИСНОЕ ВМЕШАТЕЛЬСТВО В СЛУЧАЕ ПСИХОТРАВИРУЮЩЕЙ СИТУАЦИИ}

В статье рассматриваются вопросы деятельности психолога о помощи личности в кризисной ситуации. Важным фактором кризисного вмешательства есть понимание психологом сущности кризисной ситуации, степени тяжести и механизмы ее переживания. Важное место отведено учету стадий реагирования личности, определяет стратегию и направления профессионального вмешательства. Анализируя процесс кризисного вмешательства в деятельности психолога (психологической службы) выявлень важные задачи, которые должны быть реализованы: 1) снятие симптомов 2) восстановление до кризисного уровня функционирования; 3) осознание тех событий, которые приводят к состоянию дисбаланса; 4) выявление внутренних ресурсов клиента и членов семьи в различных формах помощи для преодоления кризиса.

Ключевые слова: психотравмирующая ситуация, микро- и макротравмы, кризис, кризисное консультирование.

Bulletin of Taras Shevchenko National University of Kyiv.

Series "Psychology". № 1(10), pp. 78-81 (2019)

УДК 159.922.4

DOI: https://doi.org/10.17721/BSP.2019.1(10).20
ISSN 1728-3817

(C) Taras Shevchenko National University of Kyiv,

Publishing Center "Kyiv University", 2019

Віталій Онищенко, студ. Київський національний університет імені Тараса Шевченка, Київ, Україна

\section{РОЗВИТОК ЦІЛЬОВОЇ СПРЯМОВАНОСТІ ОСОБИСТОСТІ ПІДЛІТКІВ-ТУРИСТІВ}

Наведено результати вивчення розвитку цільової спрямованості особистості підлітків-туристів. Дослідження полягає у припущенні про те, що прискорення розвитку цільової спрямованості особистості у підлітків можливо иляхом активізації їі складових в умовах туристичної діяльності. Взаємодія у групі під час змагань та подорожей сприяє розвитку колективізму й комфортного мікроклімату, що впливає на емоційну сферу підлітків. Застосування карток орієнтовної основи дії на тренуваннях викликає пізнавальну активність, зростання мотивації до навчання, а також розвиток раціональної та альтруїстичної позицій цільової спрямованості особистості підлітків. Ситуації випробування під час тренувань та змагань, складні ділянки маршруту й несприятливі погодні умови в поході спричиняють корекцію конативного компоненту. Система змінних посад, туристичні правила та цінності сприяють розвитку ціннісного компоненту цільової спрямованості підлітків.

Ключові слова: психологічні особливості розвитку, цільова спрямованість особистості, особистість підлітка, туристична діяльність, професійний спорт.

Постановка проблеми. Актуальність дослідження визначається соціальною значущістю проблеми розвитку цільової спрямованості особистості підлітка, оскільки від її вирішення залежить якість життя зростаючої людини, її внутрішні зміни та саморозвиток. Цільова спрямованість відображається в особливостях взаємодії підлітків із навколишнім світом. Актуальність дослідження полягає також і у тому, що теоретичне визначення цільової спрямованості може стати у нагоді при розробці загальної теорії особистості, яка являє собою багатовимірну систему. Одним із таких вимірів $є$ діяльнісний, який містить потребнісно-мотиваційні, інформаційно-пізнавальні, цілеутворювальні компоненти.

Аналіз останніх досліджень і публікацій. Стосовно окресленої проблематики можна виокремити такі напрями досліджень, які стосуються особистості в цілому (В. В. Рибалка, О. П. Саннікова, Е. Фромм, К.-Г. Юнг), спрямованості особистості (О.М.Леонтьєв, К. К. Платонов, С.Л. Рубінштейн), взаємозв'язку цілей і мотивації діяльності (Б. Ф. Ломов, Є. М. Нікіреєв, В.А.Семиченко), процесів цілеутворення (О.Ф. Коган, О. К. Тихомиров) та перспективи майбутнього часу (К. О. АбульхановаСлавська, К. К. Платонов). Цільова спрямованість розглядається системно у контексті мотиваційної сфери особистості (В. С. Вуколов, О. П. Гащук, С.Д. Максименко), виконанні творчих завдань (В. Є. Клочко, В.О.Моляко), самоактуалізації духовності (Г. О.Балл, В. О. Моляко, Т. М. Титаренко), вольової організації (В. А. Іванніков, С. Д. Максименко), саморегуляції (О. Я. Чебикін), пізнавальної діяльності (П. Я. Гальперін, Н. Ф. Тализіна). Психологічні аспекти структури цільової спрямованості особистості розглядаються у працях Я. В. Васильєва.

Проблема цільової спрямованості особистості підлітків досліджувалась у контексті розвитку особистості (К. О. Абульханова-Славська, Б. Г. Ананьєв, І.Д.Бех, Л. І. Божович, М. Й. Боришевський, І І. С. Булах, В. О. Татенко, Д.Й. Фельдштейн). Існує певна низка робіт, присвячених питанням розвитку особистості підлітків шляхом використання творчого потенціалу (К. О. АбульхановаСлавська, В.О. Моляко), тренінгових занять (І.С. Булах), спортивного туризму (П. І. Істомін, О. Н. Камакін, Л. Ф. Нікішина). Водночас специфріка використання туристичної діяльності як засобу розвитку цільової спрямованості особистості підлітків не була предметом спеціальних досліджень. Для повноти зображення проблеми слід додати позашкільну діяльність у формі проведення туристичних занять (О. П. Гащук, М. Ю. Костриця), які дозволяють фрормувати вольові якості (Ю. М. Кизиченко, Н. О. Тимофееєва), активізувати пізнавальну діяльність, командний дух (Л. О. Вяткін, О. П. Гащук, Е. Е. Лінчевський), сприяють саморозвитку і самопізнанню тощо (І. В. Зорін, Є. П. Ільїн, А. Т. Перкова). 